\title{
The Swedish childhood diabetes study III: IgM against coxsackie B viruses in newly diagnosed Type 1 (insulin-dependent) diabetic children - no evidence of increased antibody frequency
}

\author{
T.Tuvemo ${ }^{1}$, G. Dahlquist ${ }^{3}$, G. Frisk ${ }^{5}$, L. Blom ${ }^{3}$, G. Friman ${ }^{2}$, M.Landin-Olsson ${ }^{4}$ and H. Diderholm ${ }^{5}$ \\ Departments of ${ }^{1}$ Pediatrics and ${ }^{2}$ Infectious Diseases, Akademiska Hospital, Uppsala University, Uppsala, \\ ${ }^{3}$ Sachs Children's Hospital, Karolinska Institute, Stockholm, \\ ${ }^{4}$ Department of Internal Medicine, Malmö General Hospital, Lund University and \\ ${ }^{5}$ Department of Medical Virology, Biomedical Centre, Uppsala University, Uppsala, Sweden
}

\begin{abstract}
Summary. Sera from essentially all Swedish children aged 0-14 years with Type 1 (insulin-dependent) diabetes mellitus with onset during an autumn period (October-December 1985) and a late spring period (May-June 1986) were selected. In all, 98 patients were analysed for IgM antibodies against coxsackie B virus serotypes 1 through 5 by a $\mu$-antibody capture radio immunoassay technique. Sera from 94 referent children matched for age, sex and residential area, collected during the same period, were also analysed. During the autumn period, 10 out of $67(15 \%)$ diabetic children were $\operatorname{IgM}$ positive while 14 out of $75(19 \%)$ of the healthy referent children demonstrated positivity. During the late spring period only one out of $31(3 \%)$ children with diabetes and two out of
\end{abstract}

$19(10 \%)$ referent children were IgM positive. In the diabetic patients, five were coxsackie B2 positive while coxsackie B1, 3,4 and 5 were represented by one to three patients each. Eight referent children were coxsackie B4 positive, six were $\mathrm{B} 3$ positive and two $\mathrm{B} 2$ positive, while no referent children were positive against coxsackie B1 and 5. During these two periods in late 1985 and early 1986 these data demonstrate no evidence of increased antibody frequency against coxsackie B virus 1 through 5 at the onset of childhood diabetes in Sweden.

Key words: Type 1 (insulin-dependent) diabetes mellitus, coxsackie $B$ virus, immunoglobulin $M$, radioimmunoassay.
Since Gamble et al. in 1969 and 1973 recorded higher levels and frequency of neutralising antibodies against coxsackie $\mathrm{B}(\mathrm{CB})$ virus in patients with newly diagnosed Type 1 (insulin-dependent) diabetes mellitus than in control subjects, there are now several such reports, most of which have found neutralizing CB antibodies more frequently in newly diagnosed diabetic patients than in healthy control subjects [1-3].

During the last few years, sensitive techniques for measurement of IgM antibodies against $C B$ viruses have been developed. In reports from Europe and Australia, paediatric diabetic patients, newly diagnosed, showed 30-39\% CB-IgM positivity compared with about $6 \%$ in control subjects using an enzyme-linked immunofluorescence assay (ELISA) [4, 5]. Gamble and Cumming applying a similar ELISA on Type 1 diabetic patient sera and control sera could demonstrate a CBIgM response more often only among the patients in the age group 0.5-2 years [6]. By the use of an immunofluorescence test CB-IgM was found at similar frequencies in children with recent onset Type 1 diabetes as in control subjects that were siblings of the patients (23 and $24 \%$, respectively) [7].
The aim of this work was to define the frequency of IgM antibodies against CB 1-5 in Swedish children aquiring Type 1 diabetes during two defined periods, and to compare this with the frequency in carefully matched healthy referent children studied during the same periods.

\section{Subjects and methods}

\section{Subjects}

The present paper is part of the nationwide case referent study in Swedish children aged 0-14 years with Type 1 diabetes mellitus onset. All of the 44 paediatric departments in the 24 Swedish counties collaborated. For each patient seven years old or more, two referent children were selected through the population registry (SPAR-DAFA) matched for sex, age, and county of residency. For ethical reasons only sera from hospital patients were allowed to be taken as reference in children who were younger than 7 years. The total material from the whole year of collection consisted of sera from 389 Type 1 diabetic patients and 321 referent children. Since the epidemiology of enterovirus infections exhibits a marked seasonal variation in temperate climates [8], sera from two different seasons, one autumn period (October-December 1985) and one late spring period (May-June 1986) 
Table 1. Outcome of matching Type 1 (insulin-dependent) diabetic patients and referent children for sex and age

\begin{tabular}{lllll}
\hline Age & Boys & & & Girls \\
\cline { 2 - 5 } \cline { 5 - 6 } & Patients & $\begin{array}{l}\text { Referent } \\
\text { children }\end{array}$ & Patients & $\begin{array}{l}\text { Referent } \\
\text { children }\end{array}$ \\
\hline $0-4$ & 11 & 10 & 10 & 10 \\
$5-9$ & 18 & 15 & 14 & 15 \\
$10-14$ & 18 & 18 & 27 & 26 \\
\hline
\end{tabular}

Table 2. Seasonal distribution of coxsackie-B-IgM-positive $(C B+)$ and negative $(\mathrm{CB}-)$ patients

\begin{tabular}{lcccccccc}
\hline & \multicolumn{2}{c}{ Patients } & & \multicolumn{2}{c}{ Referent children } \\
\cline { 2 - 4 } \cline { 7 - 8 } & $\mathrm{CB}+$ & $\mathrm{CB}-$ & all & & $\mathrm{CB}+$ & $\mathrm{CB}-$ & all \\
\hline October & 1 & 19 & 20 & & 4 & 20 & 24 \\
November & 5 & 27 & 32 & 5 & 29 & 34 \\
December & 4 & 11 & 15 & 5 & 12 & 17 \\
May/June & 1 & 30 & 31 & 2 & 17 & 19 \\
\hline All & 11 & 87 & 98 & 16 & 78 & 94 \\
\hline
\end{tabular}

were selected for this study. The outcome of the matching of patients and referent subjects is given in Tables 1 and 2. Sera were analysed without prior knowledge of the patients' status. The study was approved by the Ethics Committee at the Karolinska Institute.

\section{Collection of sera}

Sera from the patients were taken immediately after the diagnosis of Type 1 diabetes or within the first few days following diagnosis. After centrifugation, sera were sent by express mail to the collecting centre, stored at $-20^{\circ} \mathrm{C}$ for one week and thereafter at $-80^{\circ} \mathrm{C}$ until analysis 1-13 months later. Sera from referent children were sent and stored in a similar way.

\section{Antibody assay}

IgM antibodies against CB virus serotypes 1 through 5 were assayed by a $\mu$-antibody capture radioimmunoassay-technique using ${ }^{35} \mathrm{~S}$-labelled $C B$ virus as previously described in detail [9]. The cut-off point used in end-point calculations was three times the cpm value of a buffer blank and a negative serum (both gave the same cpm value), with the provision that the cut-off value should be at least $150 \mathrm{cpm}$. The specificity and sensitivity of the assay have been presented in a previous study [9].

\section{Statistical analysis}

When the statistics were calculated, the matching was dissolved and comparisons were made between patients and referent children as groups, as the preference for matching was given to the time of sampling. To be able to demonstrate a $50 \%$ difference between groups in terms of coxsackie IgM antibody frequency at the $5 \%$ significance level with a statistical power of $80 \%, 160-180$ samples would have to be studied, depending on the frequency of IgM positivity of the population analysed. As the frequency of CB-IgM positivity has been very different in earlier studies and thus not easily predicted, the higher figure was selected. In all, 192 sera were analysed. The chi square test was used for comparison of frequencies.

\section{Results}

Out of 142 sera from children during the autumn period, ten out of $67(15 \%)$ Type 1 diabetic children were CB-IgM positive. During the late spring period only one out of 31 (3\%) Type 1 diabetic children were CBIgM positive (Table 2). In the Type 1 diabetic patients, IgM against CB2 predominated with 5 cases (one of which also showed a response against CB5). Three patients were IgM positive against CB3 (one of which also showed a response against CB4). The remaining three patients were IgM positive against $\mathrm{CB} 1, \mathrm{CB} 4$ and $\mathrm{CB} 5$, one case of each.

Fourteen out of $75(19 \%)$ sera from healthy referent children during the autumn period showed CB-IgM positivity, and 2 out of $19(10 \%)$ referent children were CB-IgM positive during the late spring period (Table 2). Eight of the $16 \mathrm{CB}$ positive referent children had IgM to CB4, six to CB3, and two to CB2. None demonstrated IgM to CB1 or CB5.

\section{Discussion}

A great number of observations in both animals and man suggest a viral aetiology for at least some cases of Type 1 diabetes mellitus $[3,10,11]$. The evaluation of published seroepidemiological studies is often impaired by insufficient sensitivity and/or specificity in the methods used [12], and whether the control subjects are a representative group may easily be questioned when studying low-incidence diseases like Type 1 diabetes mellitus within large geographical areas $[4,13]$.

In the present study an apparently type-specific CBIgM radioimmunoassay [14] has been used. The selection of referent subjects from the population registry matching the index cases which represent consecutive cases in a whole country, makes this study unique. The present finding of a similarly low prevalence of specific CB-IgM in Type 1 diabetic patients as in referent subjects during the autumn period as well as the late spring period probably reflects the seasonal variation of these viral infections in the paediatric population at large. Similar figures have been reported in population studies by other investigators $[5,6]$. During the periods studied, these data do not indicate that CB viruses had any relationship to the development of Type 1 diabetes, or, more specifically, the data show that the CB-IgM frequency in the diabetic group was not $50 \%$ different from that seen in the referent group. To demonstrate smaller differences the analysis of a larger number of patients would be required.

The present finding was not completely unexpected as in our local (Uppsala county) continuous studies the incidence of CB-IgM among our new Type 1 diabetic patients fell in late 1984 [15] and stayed low during 1985. Gamble and Cumming [6] have shown that among their Type 1 diabetic patients the percentage displaying $\mathrm{CB}$ - 
IgM was virtually the same regardless of the duration of diabetes. Their results, as well as ours do not indicate a specific role for $\mathrm{CB}$ viruses in the pathogenesis of Type 1 diabetes mellitus, but on the other hand, these data do not exclude such a role as there exists a high frequency of antigenic variants of $\mathrm{CB}$ viruses attacking humans [16]; possibly with different tissue affinities including the islets of Langerhans [17, 18]. In addition, some workers have suggested, although not proved, that Type 1 diabetic patients may have an "immunological paralysis" [19] to account for the quantitatively lower titres of antibodies to $C B$ viruses found in patients with recent onset Type 1 diabetes than those found in healthy referent subjects [20]. Geographical variations in the epidemiology of diabetogenic variants of $\mathrm{CB}$ viruses and of other exogenous diabetogenic factors, possibly including other enteroviruses [21], and differences in the pattern of previous infection of nondiabetogenic CB variant in the population, may explain the variability over time and between areas in the percentage of new Type 1 diabetic patients who display CB-IgM.

Acknowledgements. This study was supported by The Nordic Insulin Foundation, the Swedish Diabetes Association, the Hoechst Diabetes Foundation and the Swedish Medical Research Council (07507, 07531). We acknowledge with thanks the help of the following coworkers: Å.Lernmark, G.Sundkvist, Malmö General Hospital, L. Nyström, Department of Epidemiology and Health Care Research, University of Umeå, Umeå; and from all Departments of Pediatrics in Sweden, M. Aili, Halmstad, H. Bäckman, Gävle, E.Carlsson, Kalmar, H.Edenwall, Karlskrona, P-O.Elfstrand, Skövde, B.W.Granström, Gällivare, I. Gustavsson, Skellefteå, L-E. Gustavsson, Östersund, A. Hallberg, Landskrona, B. Hansing, Lidköping, R. Hanås, Uddevalla, L.Hellenberg, Nyköping, E.Holmberg, Umeå, H.Hörnell, Hudiksvall, G.Jonsell, Karlstad, C.Jönsson, Sollefteå, K. Kockum, Ystad, U. Lindberg, Växjö, B. Lindblad, Mölndal, J. Ludvigsson, Linköping, V.Mazreliez, Visby, U.Myrdal, Västerås, J. Neiderud, Helsingborg, K-O. Nilsson, Malmö, B.Persson, Stockholm, P.G. Petzén, Västervik, G.Samuelsson, Vänersborg, K.Segnestam, Eskilstuna, M.Sigurs, Borås, S. Sjöblad, Lund, S. Sjögren, Örnsköldsvik, L. Skogsberg, Boden, T.Smith, Kristianstad, K.Snellman, Falun, L.Strömberg, Norrköping, U.Ståle, Ängelholm, J.Tenstam, Sundsvall, B.Thalme, Huddinge, A.Thilén, Jönköping, K.Tullus, Danderyd, O. Westphal, Göteborg, and J. Åman, Örebro.

\section{References}

1. Gamble DR, Kinsley ML, Fitzgerald MG, Bolton R, Taylor KW (1969) Viral antibodies in diabetes mellitus. Br Med J 3: 627-630

2. Gamble DR, Taylor KW, Cumming H (1973) Coxsackie viruses and diabetes mellitus. Br Med J 4: 260-262

3. Barrett-Connor E (1985) Is insulin-dependent diabetes mellitus caused by coxsackie B infection? A review of the epidemiologic evidence. Rev Infect Dis 7: 207-215

4. King ML, Bidwell D, Shaikh A, Voller A, Banatvala JE (1983) Coxsackie-B-virus-specific IgM responses in children with insulin-dependent (juvenile-onset; type 1) diabetes mellitus. Lancet I: $1397-1399$
5. Banatvala JE, Bryant H, Schernthaner G, Borkenstein M, Schober E, Brown D, De Silva LM, Menser MA, Silink M (1985) Coxsackie $B$, mumps, rubella, and cytomegalovirus specific IgM responses in patients with juvenile-onset insulin-dependent diabetes mellitus in Britain, Austria, and Australia. Lancet I: 1409-1412

6. Gamble DR, Cumming H (1985) Coxsackie B virus and juvenileonset insulin-dependent diabetes. Lancet II: 455-456

7. Orchard TJ, Atchison RW, Becker D, Rabin B, Eberhardt M, Kuller LH, La Porte RE, Cavender D (1983) Coxsackie infection and diabetes. Lancet II: 631

8. Cherry JD (1981) Nonpolio enteroviruses: Coxsackieviruses, echoviruses and enteroviruses. In: Feigin RD, Cherry JD (eds) Textbook of pediatric infectious diseases. WB Saunders, Philadelphia, pp 1316-1365

9. Frisk G, Torfason EG, Diderholm H (1984) Reverse radioimmunoassays of $\operatorname{IgM}$ and $\operatorname{IgG}$ antibodies to coxsackie $B$ viruses in patients with acute myopericarditis. J Med Virol 14: 191-200

10. Craighead JE (1980) Pathology of viral diabetes mellitus. In: Podolsky S, Viswanathan $M$ (eds) Secondary diabetes: the spectrum of the diabetic syndromes. Raven Press, New York, pp 487-492

11. Yoon J-W, Ray UR (1985) Perspective on the role of viruses in insulin-dependent diabetes. Diabetes Care 8 [Suppl. 1]: 39-44

12. Pattison JR (1983) Tests for coxsackie B virus-specific IgM. J Hyg Camb 90: 327-332 (editorial)

13. Eggers HJ, Mertens TH, Grüneklee D (1983) Coxsackie infection and diabetes. Lancet II: 631

14. Torfason EG, Frisk G, Diderholm H (1984) Indirect and reverse radioimmunoassays and their apparent specificities in the detection of antibodies to enteroviruses in human sera. J Med Virol 13: 13-31

15. Tuvemo T, Frisk G, Friman G, Ludvigsson J, Diderholm H (1988) IgM against coxsackie $B$ viruses in children developing type 1 diabetes mellitus - a seven-year retrospective study. Diabetes Res 9: $125-129$

16. Prabhakar BS, Haspel MV, McClintock PR, Notkins AL (1982) High frequency of antigenic variants among naturally occurring human coxsackie $\mathrm{B} 4$ virus isolates identified by monoclonal antibodies. Nature 300:374-376

17. Gladisch R, Hofmann W, Waltherr R (1976) Myokarditis und Insulitis nach Coxsackie-Virus-Infekt. Z Kardiol 65: 837-849

18. Yoon J-W, Austin M, Onodera T, Notkins AL (1979) Virusinduced diabetes mellitus: isolation of a virus from the pancreas of a child with diabetic ketoacidosis. N Engl J Med 300: 1173-1179

19. Drash A, Cavender D, Atchison R, Becker D, Eberhardt M, Laporte R, Kuller L, Orchard T, Rabin B, Wagener D (1984) Pittsburgh diabetes mellitus study: studies on the etiology of insulindependent diabetes mellitus with special reference of viral infections. Behring Inst Mitt 75: 58-72

20. Palmer JP, Cooney MK, Ward RH, Hansen JA, Brodsky JB, Ray CG, Crossley JR, Asplin CM, Williams RH (1982) Reduced coxsackie antibody titres in Type 1 (insulin-dependent) diabetes patients presenting during an outbreak of coxsackie B3 and B4 infection. Diabetologia 22: 426-429

21. Buschard K, Madsbad S (1984) A longitudinal study of virus antibodies in patients with newly diagnosed type 1 (insulin-dependent) diabetes mellitus. J Clin Lab Immunol 13: 65-70

Received: 13 October 1988

and in final revised form: 3 July 1989

Dr. T. Tuvemo

Department of Pediatrics

Akademiska Hospital

S-75185 Uppsala

Sweden 